\title{
Growth and distribution endogenously determined: a theoretical model and empirical evidence
}

\author{
Crescimento e distribuição endogenamente determinados: \\ um modelo teorético e evidência empírica
}

\author{
HERNÁN BORRERO **** \\ NESTOR GARZA $\times, \times$
}

RESUMO: Baseados em uma característica já conhecida, mas pouco desenvolvida, da teoria do crescimento: a importância da distribuição de ativos em uma função de produção agregada, nós elaboramos um modelo simples de dois indivíduos, e depois generalizamos suas deduções para um modelo estendido de $n$ agentes, concluindo que o capital produtivo perfeitamente distribuído leva a um crescimento "endógeno" positivo e ótimo de longo prazo. A literatura empírica recente e clássica sobre o tema sugere essa interpretação. Além disso, encontramos evidências de dados de painel exploratório que apoiam nossa teoria de crescimento e distribuição em um conjunto de países latino-americanos.

PALAVRAS-CHAVE: Crescimento; distribuição de ativos; desigualdade; América Latina; função de produção.

ABSTRACT: We build upon an already known but scarcely developed feature of growth theory: the importance of asset distribution in an aggregate production function. We elaborate on a simple model of two individuals, and then generalize its deductions to an extended model of $n$ agents, concluding that perfectly distributed productive capital leads to positive and optimum long-run "endogenous" growth. Recent and classical empirical literature on the topic suggests this interpretation. In addition, we find exploratory panel data evidence that supports our theory of growth and distribution in a set of Latin American countries. KEYWORDS: Growth; asset distribution; inequality; Latin America; production function. JEL Classification: O10; O41; O54.

* Universidad del Norte, Barranquilla, Colombia. E-mail: hborrero@uninorte.edu.co.

* Hernán Borrero wishes to thank Colfuturo for supporting him during his postgraduate studies at the University of Bristol, United Kingdom.

× California State University at Dominguez Hills, Carson - CA, United States. E-mail: ngarza@csudh. edu

${ }^{\times \times}$Nestor Garza is also associated of Universidad del Norte, Barranquilla, Colombia. E-mail ngarza@ uninorte.edu.co. Submitted: 6/September/2017; Approved: 26/July/2018. 
All the problems that the socialists proposed to themselves, cosmogonic visions, revery and mysticism being cast aside, can be reduced to two principal problems. First problem: To produce wealth. Second problem: To share it.

The two problems require to be solved together, to be well solved. The two problems must be combined and made but one.

Victor Hugo, in Les Misérables.

\section{INTRODUCTION}

This clear-cut observation of Victor Hugo synthesizes the entire purpose of this paper: To find a "combined" solution to the economic problem of growth and distribution. This question is still valid, especially in developing countries: those that followed the route of "England" and "Venice", as the author continues, certainly experimented fast growth, but of little or no benefit at all for most of their population; while those that followed the route of "Communism" endeavored at distributing wealth more evenly but annihilated their productive apparatus.

David Ricardo (1985) had already identified the problem of distribution as the cornerstone of the entire economic system. As he wrote to Thomas Malthus:

Political Economy you think is an enquiry into the nature and causes of wealth - I think it should rather be called an enquiry into the laws which determine the division of the produce of industry amongst the classes who concur in its formation. No law can be laid down respecting quantity, but a tolerably correct one can be laid down respecting proportions. Every day I am more satisfied that the former enquiry is vain and delusive, and the latter only the true objects of the science (Letter dated 9 October, 1820, Works (Sraffa edition), Vol. VIII, pp. 278-9, cited by Kaldor, 1955).

Indeed, it was based on these "laws" that he aspired to formulate "a simple macro-economic model", and since then various theoretical attempts have been endeavored. Specifically, Kaldor (1955) himself identifies four main strands of thought: The Ricardian or Classical Theory, the Marxian, the Marginalist or Neo-Classical Theory, and the Keynesian; all of which (except for Keynes) have certainly considered Ricardo as their precursor, and built their economic models upon his.

As Kaldor masterfully exposes, these four strands of thought have quite different assumptions and "laws which regulate distributive shares": In the Ricardian and Marxian Theory, on the one hand, it is the "Surplus Principle", where the sup- 
ply of labour is assumed to be perfectly elastic (in the former, because of a "natural rate of wages" fixed in terms of "corn"; and in the latter, because of the existence of a "reserve army" of labourers that prevents wages from rising above a subsistence level, or the cost of "reproduction" of labour, fixed in terms of commodities in general) and the capitalists appropriate all surplus value from labour in the process of accumulation, which governs these distributive shares; whereas in NeoClassical Theory, on the other, it is the "Marginal Principle", where both labour and capital are remunerated on the basis of their respective marginal productivities, which determine the shares of each. Finally, in the Keynesian Theory, improved by Pasinetti (1962), it is the "Multiplier Principle", where the investment to output ratio determines the share of profits in income through a coefficient of sensitivity built on the difference of the capitalists' and wage-earners' marginal propensities to save. However, and despite of their marked differences, all these theories put in the center of the entire distributive and accumulative problem the "Classical" dichotomy of profits and wages, or the division of society in the two broad classes of capitalists and wage-earners or "proletariat".

Thus, the problem of distribution becomes a problem of how productive factors (mainly capital and labour) are remunerated, but not a problem of how the factors themselves are distributed, which is a problem prior to the issue of remuneration, and a more general one. In fact, as Chenery et al. (1976) put it, the origin of every income inequality (profits and wages) is found in a more substantial productive factor inequality: effectively, if all individuals possessed equal quantities of every factor, then income distribution would be the same for everyone, independently from the relative remunerations paid for each. Thus, it is the problem of factor endowments (defined as land, physical capital and human capital) what is in the core of the entire distributive problem, and consequently, it is the principal lacking element of all the existing theories of growth and distribution.

In other words, the main problem of "political economy" is not merely the "division of the produce of industry amongst the classes who concur in its formation", as Ricardo stated, but more generally, the "division of productive factors amongst the people". Hence, in this paper we formulate and test a simple macro-economic model based on this understanding of the matter, which certainly takes us away from the presented traditions. We face the overall problem from a completely different approach where, as for Victor Hugo, growth and distribution are two sides of the same coin.

\section{THE BASIC MODEL}

Imagine a Robinson Crusoe type of economy, where there are only two individuals, $A$ and $B$, and only one productive factor, capital $(K)$, which is assumed to be completely homogeneous, and of limited availability. Hence, each individual has a certain capital endowment $K_{i}$ (where $i$ represents any of the two individuals, and the sum of the two endowments equals the total capital available in society, $K)$, and produces with the same production function of the type $K_{i}^{\alpha}$, exhibiting diminishing 
returns to capital; which, at turn, depreciates at the same constant rate of $\delta K_{i}$. Furthermore, each individual's personal income or produce $Y_{i}$ is given by its production function, and the aggregate income or produce $Y$ is simply given by the sum of the personal incomes of both. Thus, we can write the following fundamental identities:

$$
\begin{aligned}
& Y=K_{A}^{\alpha}+K_{B}^{\alpha} \\
& K=K_{A}+K_{B}
\end{aligned}
$$

Moreover, for each individual the rate of capital accumulation, $r_{i}$, is equal to the difference between the corresponding production and depreciation functions, or:

$$
r_{i}=K_{i}^{\alpha}-\delta K_{i}
$$

And the rate of growth of the total economy $g$, can be written as:

$$
g=K_{A}^{\alpha}-\delta K_{A}+K_{B}^{\alpha}-\delta K_{B}
$$

This description of a capitalistic economy certainly deviates from the traditional description of "dual economies" or two sector models as those developed by Lewis (1954) and Harris \& Todaro (1970) where a "modern", urban sector, coexists with a "traditional", rural sector; and where society is essentially divided between "capitalists" and "wage-earners", following the Marginalist tradition (in our model, the two individuals are, in fact, "capitalists", despite of their different relative capital endowments $)^{1}$. However, this is done for three important reasons: First, the traditional-modern sector division is only specific of underdeveloped countries, and we are proposing a more general theory. Second, what defines these two sectors is, in essence, not their rural-urban nature, but the fact that in the traditional sector there is a longstanding surplus labour force (that lives near a subsistence level and migrates to the urban sector in search for higher wages) and a lack of capital and capitalistic activities (those endeavored by "capitalists"), found in the modern sector only. Therefore, because nowadays "reserve armies" are not exclusive of rural areas, but also of urban centers, and because it is the presence or absence of capital and capitalistic activities what more broadly defines these two sectors, then it is sufficient to divide the society more generically between individuals (or socio-economical groups, if desired) with high or low levels of capital endowments, as we do between $A$ and $B$. And third, if any of the individuals, or both, can hire each other at any given wage rate, in the aggregate, the effect on income $Y$ would be null, leaving capital endowments as the only element relevant for the analysis. More explicitly, if $A$ can be hired by $B$ at any given wage rate $w_{B A}$ (the wage rate paid by $B$ to $A$, for the employment of $A$ in the use of $B$ 's production function), but $B$ can also be hired by $A$ at a given wage rate $w_{A B}$ (the wage rate paid by $A$ to $B$, for the employment of $B$ in $A$ 's production function), then, the

\footnotetext{
${ }^{1}$ It can resemble more clearly a currently developing country, with an overwhelming preponderance of survivalist labour informality as represented by single-person firms. Each one of them fully "owns" her own capital and adds labour services (Williams \& Nadine, 2012).
} 
personal income for each would be equal to the salary perceived from the counterpart plus the profits $p_{i}$ left after paying any salary to the counterpart:

$$
\begin{aligned}
& Y_{A}=w_{B A} K_{B}^{\alpha}+p_{A} K_{A}^{\alpha} \\
& Y_{B}=w_{A B} K_{A}^{\alpha}+p_{B} K_{B}^{\alpha}
\end{aligned}
$$

Where $p_{A}=\left(1-w_{A B}\right)$, and $p_{B}=\left(1-w_{B A}\right)$. Thus, the aggregate income function would be:

$$
Y=p_{A} K_{A}^{\alpha}+w_{B A} K_{B}^{\alpha}+p_{A} K_{A}^{\alpha}+w_{B A} K_{B}^{\alpha}
$$

Replacing in the above aggregate income function $p_{A}$ and $p_{B}$ by their corresponding identities and simplifying the expression, then we are back to the simple aggregate income function [1]. Thus, the only element relevant for our analysis, as said before, are capital endowments, and wage "linkages" among individuals (or socio-economic groups) can be safely disregarded. In fact, this also proves that the underlying element in the problem of growth and distribution is not the share of profits $p$ and the share of wages $w$ in the total income (as in all four strands of thought introduced in this work); it is factor endowments (capital, in this case) what underlies everything.

We describe graphically our model in Figure 1: If on the horizontal axis we represent all the capital endowment of society, $K$, and position $A$ on the left corner and $B$ on the right, then all the capital measured from left to right is the capital owned by $A$, and all the capital measured from right to left is owned by $B$. On the left vertical axis, thus, we measure $A^{\prime} s$ personal income, produced out of $A$ 's production function, and the same we do for $B$ on the right vertical axis; finally, we draw the corresponding depreciation curves for each individual as well, as the straight lines beginning at each corresponding individual's vortex and extended to the point where they cross with each corresponding individual's production function (this trait is due to the diminishing rate of production and the constant rate of depreciation). Thus, for each individual, the rate of capital accumulation, $\left[r_{i}\right]$ is equal to the vertical distance between the corresponding production and depreciation curves.

Figure 1: The simple Model of Growth and Distribution

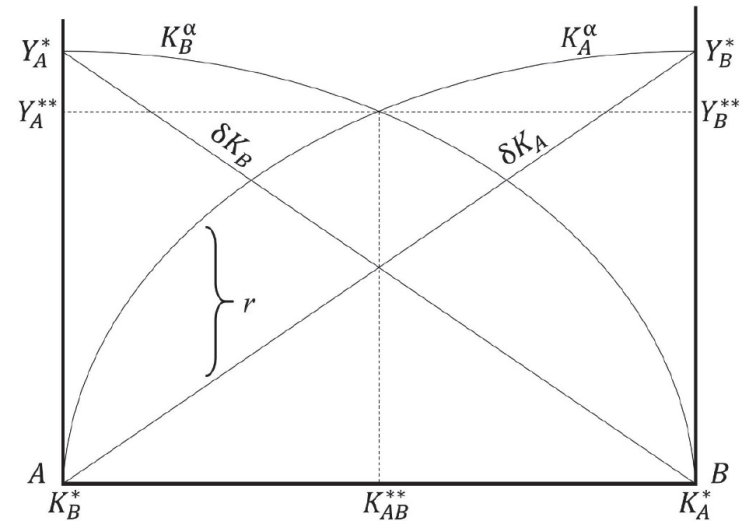


Notice that if $A$ owned all capital in society, a situation marked by $K_{A}^{*}$, individual $A$ would have an income equal to $Y_{A}^{*}$, whereas $B$ would have no income at all. Most importantly, however, the difference between the production and depreciation functions for both individuals (the rate of capital accumulation, $[r]$, for each) would be equal to zero, and the economy would be in a "Steady State", such as that described by Solow (1956), where there is zero capital accumulation in the long run. The same could be said of a situation defined by $K_{B}^{*}$. However, at any possible distribution of capital in between these two extreme situations, say, a little bit to the left of $K_{A}^{*}$, individual $A$ would have a higher income level than $B$. But the fundamental interpretation of our model is that, under this (yet uneven) distribution, there will be a positive rate of accumulation for each individual and a positive rate of growth for the economy as whole.

Now, in order to solve the problem of growth and distribution altogether, it is forthright to find the maximum rate of growth obtainable in this system and the corresponding optimal distribution of capital among the two individuals. Hence, by expressing [2] in terms of $K_{A}$ and replacing it in [4] (exactly the same analysis can be made by using equation [1] instead), we get:

$$
g=\left(K-K_{B}\right)^{\alpha}-\delta\left(K-K_{B}\right)+K_{B}^{\alpha}-\delta K_{B}
$$

And we can maximize the growth rate of the economy by deriving this last equation with respect to $B^{\prime}$ s personal capital holdings (the "variable") and equating the resulting expression to zero, to find a "maximum":

$$
\begin{aligned}
& \frac{d g}{d K_{B}}=-\alpha\left(K-K_{B}\right)^{\alpha-1}+\delta+\alpha K_{B}^{\alpha-1}-\delta=0 \\
& \alpha K_{B}^{\alpha-1}=\alpha\left(K-K_{B}\right)^{\alpha-1} \\
& K_{B}=K-K_{B} \\
& K_{B}=\frac{1}{2} K
\end{aligned}
$$

Due to symmetry, the same result is valid for $K_{A}$; that is, at the level where the rate of growth (and the aggregate production as well, as proved when using equation [1]) of this two-individual society is maximum, both $A$ and $B$ will have, each, a capital endowment which is exactly half of all the capital available in the economy. Graphically, this situation is illustrated in Figure 1 by the arrangement $K_{A B}^{* *}$, and its corresponding personal income levels, $Y_{A}^{* *}$ and $Y_{B}^{* *}$. As said, at this schedule of capital endowments, the growth rate of the economy $g$ and the total income $Y$ are maximized.

But there are two other important interpretations of this result: First, because there is a maximum, then the system is "stable". This means that the system will eventually converge to the new "Steady State" of maximum growth and income in the long run. To see why, we can try a numerical example: If the total capital available in society $K$ was equal to 100 units, 90 of which were owned by $A$ and 10 by $B$ (which is equivalent to a $90 \%$ to $10 \%$ distribution); if their respective production functions were $K_{A}^{1 / 2}$ and $K_{B}^{1 / 2}$; and for each, capital depreciated at a constant rate 
of 0.1 , then, at the present time $(t=0)$, the rate of accumulation $r$ of individual $A$ would be equal to 0.49 , and that of individual $B$ would be equal to 2.16 (as the reader can check by himself by using equation [3]). This means that by the next period $(t=1)$, individual $A$ would have a total capital endowment of 90.49 and individual $B$ of 12.16 (which is now equivalent to a $88.15 \%$ to $11.85 \%$ distribution). Now, their respective accumulation rates would be 0.46 and 2.27 , and by period $(t=2)$, each would have a capital endowment of 90.95 and 14.43 respectively (an equivalent $86.31 \%$ to $13.69 \%$ distribution). Consequently, $A^{\prime} s$ share of capital will decrease on time and $B^{\prime} s$ share will increase until they are both the same (that is, $50 \%$ for each). At that point, the rate of accumulation and its magnitude will be the maximum possible and the same for both, and thus it will be maintained in the long run once reached. Directly from this observation, we derive our second reading of the obtained result: Positive growth is possible "endogenously" even in the long run, thus contradicting Neo-Classical growth theories of the Solow and Ramsey types, where this feature is only possible due to "exogenous" forces, mainly to the rate of technological advance. Here, distribution is the endogenous force that determines growth; and the more equalitarian the distribution of capital in this two-individual society is, the more growth can be obtained. Moreover, "perfect distribution" is a condition for maximum growth.

As the reader has probably noted already, the above is true for every possible original capital distribution between the two individuals, except for the two extreme cases where individual $A$ or $B$ owns $100 \%$ of the capital available in society, and the counterpart owns $0 \%$. Only in these two extreme cases, the rate of accumulation for both is equal to zero, and thus the distribution schedule is also preserved in the long run (describing, as said, the Solow equilibrium, or "Golden Rule"). Here, we are not only back to the old Neo-Classical theory of growth, but also back to the capitalist/wage-earner dichotomy, where all profits from capital are obtained by the capitalist and where wage is the only source of income for the dispossessed, as can be deducted from equations [5] and [6]. What's more, social income $Y$ is less than what otherwise could be under any other distribution schedule (actually, it is the minimum social income possible). However, although the social product is suboptimal, the "almighty" owner has more personal income than in any other possible setting of endowments, and thus has no incentive to give away any fraction of his wealth. Graphically, a horizontal "Small Push" towards the middle distribution is thus needed to oblige the situation to become a bit less uneven, so that the system can operate solely towards perfect distribution in the way described above. Moreover, a horizontal "Big Push" (not in Rosenstein and Rodan's (1943) original sense of a massive injection of capital into the economy, equivalent to a simple widening of the box in Figure 1, without any change in the suboptimal conditions; but in the sense of a horizontal thrust towards equality) can be undertaken to accelerate the process of arriving at the perfect distribution scheme (which, as the reader noticed in our numerical example, can be actually very slow) by reorienting a fixed proportion of the accumulation achieved at any point in time from the rich to the poor (as proposed by 
Chenery et al. (1976) as well, in terms of a "dynamic redistribution”), or by doing an effective transfer of existing capital from one individual to another, in a more "revolutionary" fashion. Interestingly, it is not a "critical mass of investment" (Ros, 2013) what launches this economic boost, but rather, it is the efficient allocation of the resources already available in the economy among its participants what really leads to higher growth and development. Yet, unless the capitalist "Lord" renounces voluntarily to part of his endowment, this effort can only been undertaken coercively. In the terminology of Hobbes (2010), the existence of a "Leviathan" (a Dictator or a Democratic Reform) is thus needed.

\section{THE EXTENDED MODEL}

Now, the previous simple two-individual model can be generalized through the principle of mathematical induction for a society of $N$ individuals, where $N$ is a positive large, but finite number. Graphically, this would look more or less like a "Sand Clock", or a "Space Wormhole" (try a tri-dimensional unfolding of our simple two-individual model of Figure 1), but we leave to the reader's imagination the picturing of such an economy. Here, we focus in the exposition of the mathematical exercise: Again, capital $(K)$ is the only productive asset, and each individual possesses a certain capital endowment of $K_{i}$ (where $i$ represents now any of the $N$ individuals, and the sum of all individual endowments equals the total capital available in society, $K)$, and produces with the same production function as expressed before $\left(K_{i}^{\alpha}\right)$. Once more, capital depreciates at a constant rate of $\delta K_{i}$. In this context, we can now write the following basic identities of aggregate income $(Y)$, economic growth $(g)$, and capital availability $(K)$ :

$$
\begin{aligned}
Y & =\sum_{i=1}^{N} K_{i}^{\alpha} \\
g & =\sum_{i=1}^{N}\left(K_{i}^{\alpha}-\delta K_{i}\right) \\
K & =\sum_{i=1}^{N} K_{i}
\end{aligned}
$$

Once more, we can solve the problem of growth and distribution altogether through a process of maximization. Hence, the problem can be described as one of maximizing [14] subject to [15] (this last identity as the "equality constraint", passing the term in the right to the left of the expression in order to equalize it to zero), and so we can write the following Lagrangian:

$$
L\left(K_{i}, \lambda\right)=\sum_{i=1}^{N}\left(K_{i}^{\alpha}-\delta K_{i}\right)+\lambda\left(\sum_{i=1}^{N} K_{i}-K\right)
$$

From which deriving partially with respect to any two $K_{j}$ and $K_{n}$ random capital endowments (possessed by any two $j$ and $n$ different owners who belong to 
the set of $N$ individuals), as well with respect to $\lambda$, and equalizing each partial derivative to zero, we get:

$$
\begin{aligned}
& \frac{\partial L}{\partial K_{j}}=\alpha K_{j}^{\alpha-1}-\delta+\lambda=0 \\
& \frac{\partial L}{\partial K_{n}}=\alpha K_{n}^{\alpha-1}-\delta+\lambda=0 \\
& \frac{\partial L}{\partial \lambda}=\sum_{i=1}^{N} K_{i}-K=0
\end{aligned}
$$

And from [17] and [18], we obtain $K_{j}=K_{n}$, or that for any two $K_{j}$ and $K_{n}$ singular capital endowments, economic growth is maximized when each individual has the same amount of productive assets. Furthermore, because at the optimum distribution, $K_{1}=K_{2}=\ldots=K_{N}$, we can rewrite [19] as follows:

$$
\begin{aligned}
& N K_{i}-K=0 \\
& N K_{i}=K \\
& K_{i}=\frac{K}{N}
\end{aligned}
$$

That is, the problem of growth and distribution is solved when capital is distributed symmetrically amongst all the members of society. Furthermore, we prove once again that the system is stable, leading to a "Steady State" of endogenous positive growth and perfect distribution.

As we can see, Neo-Classical exogenous growth theory is challenged once more. Moreover, we argue that any theory of growth and distribution built on it, such as that of Stiglitz (1969), will necessary lead to confusion. This will happen because the Neo-Classical model pictures the economy as just one side of our two-sided model of Figure 1, as if capital was uncontested within the economy, and as if it was governed by a single agent, or the Nation as a single producer. But the truth is that in capitalistic economies, productive assets are not governed by the Nation as if it was a single owner, but rather by individuals and firms, who actually compete fiercely for capital within an economy. And thus, an economy should not be viewed as having a single production function, such as that drawn by Solow (1956), but rather as the convergence of multiple production functions, as we intend to show in our "Space Wormhole Economy". It is the equilibrium among these multiple functions what should be found in order to solve the problem of growth and distribution altogether. No wonder Stiglitz's (1969) assertion that equality in wealth and income distribution is reached when the economy is at a stable equilibrium of zero growth; when, in reality, is the other way around ${ }^{2}$.

\footnotetext{
${ }^{2}$ It is worth mentioning that we are using individual decisions which are then aggregated via simultaneous determination of distribution and output (convergence at maximum income after a "little push" in capital endowments). This strategy is the opposite to using a representative agent, which is the microeconomic foundation for neoclassical theories of either exogenous or endogenous growth (Garza \& Pugliese, 2009).
} 


\section{LITERATURE REVIEW}

Victor Hugo's view of the problem of capitalistic societies as a linear debacle towards extreme poverty and excessive wealth - Plato's two "evils" of society (i.e., The Republic) -, was refined by Kuznets (1955), where initial vigorous capitalist accumulation increased inequality, but growth rate dropped in late and less unequal stages. Recent information does not support such a view: in the case of Latin America, income per capita remains relatively low (slightly above $1 / 4$ of income per capita in the OECD countries), and inequality high (in the countries of our sample, the Gini index remains on average around 0.5).

Kuznets' inverted U curve rapidly turned itself into the "backbone" of all the proceeding studies on the relationship between growth and distribution, many of which were essentially endeavored at testing empirically his hypothesis using econometric methods. Nevertheless, as more data is gathered and as the tests get perfected, this relationship appears every time more elusive (i.e., Birdsall \& Londoño, 1997, Deininger \& Olinto, 2000). From these evaluations, instead, a more meaningful nexus emerged amongst growth and asset inequality. Furthermore, inequality is no longer understood to be a consequence of growth, as in Kuznets' tradition (including dual economy models, such as that of Lewis (1954)), but rather, an important constraint to growth through different channels. In sum, it can be said that the empirical research on the subject can be characterized by three important transitions: 1) from the use of "scanty" cross-sectional data and time series (as Kuznets himself admits), to the completion of "high quality" panel data, such as that achieved by Deininger and Squire (1996), with every time more and more observations that allow for a more complete picture of the problem; 2) from the skimpy concept of income inequality to the more fundamental aspect of asset inequality (commonly using land and human capital inequality as "proxies" to asset inequality, or as variables of an interest for themselves) (i.e., Castelló \& Doménech, 2002; Pak Hung Mo, 2003; Fort, 2007; Grinberg, 2015; and Frankema, 2010); and 3 ) from the understanding of inequality as a consequence of growth, to the view of inequality as an impediment to growth, finding a significant and strong negative relation between asset inequality and economic growth. We build upon this empirical tradition, but we test our theoretical framework in which growth and distribution are simultaneously (endogenously) determined.

Parallel to the above copious stream of research, the arena of quasi-experimental methods includes the contribution of Sokoloff and Engerman (2012), who analysed the development patterns followed by the newly formed countries during the colonization of the Americas (one of the economic history's greatest "laboratories"). The economic performance of these societies diverged, not because of any particular trait of the colonizers, but instead, because of a more elementary contrariety of each individual country's factor endowments: Whereas some of them were relatively scarce in land, others were relatively scarce in labour. This caused land, in the former ("Jamaica" type of countries), to be of extreme value and to be withheld by the few, while the remuneration of the many labourers (or actual "reserve armies", partly 
composed of slaves) remained near the mere "levels of subsistence", as predicted by Marxian Theory. Subsequently, in these colonies, extremely high wealth gaps were created, and political power was taken over by the newly formed "elites", thus perpetuating this scheme of inequality overtime and impeding economic growth in the long-run. On the contrary, countries with relatively scarce labour and abundant land (United States and Canada) allowed majorities to participate from the gains of land (and of commerce) and to access political power to secure a scheme of equality and democracy that could enhance growth in the long-run.

Therefore, based on the findings from both econometric and quasi-experimental methods, the hypothesis of our paper that the more evenly distributed the productive assets are amongst the members of society, the higher the level of economic growth (the view of growth and distribution as "two sides of the same coin"), seems to be robust. Ultimately, perfect asset distribution shall lead to optimum economic growth, a result essentially reliant on the "Law of Diminishing Returns". Consequently, Kuznets' call for resilience in the face of extreme inequalities and in hope for future economic development (the view of inequality as the prelude of a better "afterlife") appears to be anything but necessary, and the view of inequality as the watchdog of the economic "underworld" seems to be more proper.

In this new context, moreover, stability and convergence in the long-run should also be understood in a different way as to what has been presumed up to now by the Neo-Classical theory of growth: countries do not converge to a steady state of zero endogenous growth, but towards equality and positive endogenous growth. This theoretical result is tested in the following section.

\section{Empirical Model and Control Variables}

We test our theoretical prediction by using a panel data of six Latin American countries (Brazil, Chile, Colombia, Honduras, Mexico, and Venezuela) for a 22-year period (1990-2011). This sample is limited by information availability, all provided by the World Bank (WB) and the United Nations Economic Commission for Latin America and The Caribbean (ECLAC). Although we acknowledge that these countries have relatively different levels of economic development, they do share historic, cultural, and societal characteristics. In addition, their income differences are proportionally small when compared with western societies, or with other developing countries (like in Sub-Saharan Africa).

We are also aware that parameters estimated with small samples have larger standard errors and are less likely to find significant relationships (Type II error). Therefore, we choose to work with a $90 \%$ confidence interval instead of the traditional $95 \%$, but the trade-off of such a decision is that we are more exposed to Type I error. Thus, we will interpret our regressions as exploratory results, a first approach to the theoretically predicted relationship between growth and distribution, and leave for future contributions (by ourselves or other authors) extended tests to the theory proposed in this paper.

To perform the empirical test, consider the following production function: 


$$
Y=f\left(D_{K}, K, L\right)
$$

Where $D_{K}$ stands for productive capital distribution, the only novelty in the old production function. Whereas measures of $Y$ (gross domestic product, in dollars), $K$ (gross fixed capital formation, or investment, in dollars) and $L$ (economically active population) are easy to find, $D_{K}$ is obtained in two stages: in the first stage, assume that the total income distribution is composed by the sum of the proportionate distributions of labour income and capital income (measures of 'income' distribution are widespread), leading to the following linear equation:

$$
T d=(L / Y) L d+(K / Y) K d
$$

Where $T d$ is the Gini Coefficient of [total] income distribution, $L d$ is the Gini Coefficient of labour income distribution, and $K d$ is the Gini Coefficient of capital income distribution, while the $(L / Y)$ and $(K / Y)$ ratios stand for the proportion of labour and of capital in the aggregate product of the economy. In the second stage all but one of the components are constructed from the available data: $T d$ and $L d$ are obtained from the total and labour percentage income distributions by deciles, while the $(L / Y)$ ratio is obtained from the division of total labour income over aggregate output, and $(K / Y)$ is simply its complement. $K d$ has been cleared from the equation.

We know that capital-income inequality is not exactly the variable required by our theory; however, we are determining the income inequality that arises solely from capital. In other words, changes in the Gini Coefficient of capital income distribution $(K d)$ will necessarily reflect changes in capital endowments $\left(D_{K}\right)$, which is what we are interested in (Piketty \& Zucman, 2014). Nonetheless, a crucial shortcoming with this measure is that Gini indexes fail to catch up the highest incomes, as they are commonly built on the distribution of income by quintiles or deciles of the population. This arguably makes it not a very strong proxy for capital distribution, which is known to be highly concentrated in the upper $1 \%$ of the society (Saez \& Zucman, 2016). Thus, by using this proxy variable we might not be able to capture the whole effect of capital distribution on growth, and our results might be well underestimated. However, this also means that if this variable has some predictive power, then the true effect might be even stronger than it appears.

Now, going back to equation [23], we follow the convention and divide both sides of the equation by $L$ to express it in per worker terms:

$$
(Y / L)=f[K d,(K / L), 1]
$$

For empirical purposes, $L$ is the total employed people in the economy, and not the economically active population. Then, rewriting [25] in logarithmic terms to express it in growth rate form we have:

$$
\ln (Y / L)_{i t}=\beta_{0}+\beta_{1} \ln (K d)_{i t}+\beta_{2} \ln (K / L)_{i t}+\beta_{X} \ln (X)_{i t}+E_{i t}
$$

Where $(Y / L)$ is the gross domestic product per worker in dollars, $K d$ is the Gini Coefficient of capital income distribution expressed in percentage terms, $K$ / L 
is the gross fixed capital formation [or investment] per worker in dollars, and $E$ stands for the error term in the equation for every country $i$ and year $t . X$ is a vector containing additional independent variables relevant for economic growth extracted from some of the main economic development explanations: First, in the Lewis theory of dual economies, it is the expansion of the modern industrial sector what fosters economic growth. However, because in the last century the services sector has become equally important as a source of development (i.e., financial markets, transport, etc.), we follow Gollin et al. (2016) in including a broader concept of 'modern sector'. We name this variable $M$ : the sum of the proportions of the industrial and services sector in aggregate output.

Second, the level of democracy $(D)$, scaled from one to seven (where one is the lowest level of freedom, and seven is the highest) ${ }^{3}$, is also included in the regression. This is so because democratic institutions have received considerable attention during the last decades, as they seem to promote economic growth by securing property rights (Doucouliagos \& Ulubaşoğlu, 2008; Sokoloff \& Engerman, 2012). As a critique to this tradition, Chang (2011) objects its determinism and orientation to Anglo-Saxon institutional systems, which does not acknowledge other institutional schemes that have proved equally (or more) successful in promoting fast economic growth. In addition, Glaeser et al. (2004) argue that current measures do not adequately represent the theoretical political institutions that they proxy. For instance, dictators who chose to respect property rights are coded differently than democracies. However, we believe that our measure of democracy (retrieved from the ECLAC) overcomes these criticisms because it builds on different integral components of political rights and civil liberties. Anyhow, the referenced authors conclude that many of the empirical works that try to prove the 'institutional' argument (according to which democratic institutions cause growth) are flawed and that human capital is a more basic source of economic growth.

Thereof, in the third place, we include the level of human capital $(H)$, measured as the average schooling years of the economically active population over 15 years of age (retrieved from the ECLAC as well). The positive impact of education on growth is a relatively well-established fact, either because it generates positive technological externalities or because it leads to political stability that reduces violence and secures property rights (Aisen \& Veiga, 2013).

A summary of the independent variables, their theories of precedence, and their expected signs, is provided in Table 1. According to our theory, the sign of the slope coefficient of $K d$ should be negative, whereas it should be positive for the remaining variables in accordance with the economic theory of their origin.

\footnotetext{
${ }^{3}$ The original democracy index from the ECLAC is inverted ( 1 is the highest level of freedom, and 7 is the lowest), but we shifted it the other way around to facilitate its interpretation.
} 
Table 1: Summary of Independent Variables

\begin{tabular}{|c|c|c|c|}
\hline & Variable Description & Theory of Origin & Expected Sign \\
\hline$K d$ & Gini Coefficient of capital income distribution (\%) & Growth \& Distribution & Negative \\
\hline$K / L$ & Gross fixed capital formation per worker, in dollars & Solow- Swan & Positive \\
\hline M & Modern sector (industry plus services) in aggregate output (\%) & Lewis & Positive \\
\hline$D$ & Democracy index, from one to seven & Sokoloff-Engerman & Positive \\
\hline$H$ & Human capital (average schooling years of EAP) & Sokoloff-Engerman & Positive \\
\hline
\end{tabular}

\section{Estimation Process}

We check the stationarity of the series in our panel database and the order of integration using separate panel Unit Root tests at levels. The criteria of a 0.95 level of significance is adopted, with automatic observation-based lag selection following the Schwartz Information Criterion. The Null Hypothesis (i.e. the presence of a Unit Root) is not rejected in most of the tests, suggesting that the panel series are non-stationary. The outcomes of the tests with and without individual intercept and trend are summarized in Table 2.

Table 3 shows the panel Unit Root tests applied to the first differences of the series. The Null Hypothesis is rejected in the majority of cases, proving that the panel series are $I(1)$, or that they become stationary when taking their first difference.

The Kao's (Engle-Granger) Residual Cointegration Test (KRCT), with automatic observation-based lag selection using Schwartz Criterion, rejected the Null Hypothesis (i.e., the variables are not cointegrated) with $1 \%$ margin of error, implying a long-run relation among the variables used in Tables 2 and 3.

Table 2: Panel Unit Root tests on series in levels

\begin{tabular}{|c|c|c|c|c|c|c|c|c|}
\hline & \multicolumn{4}{|c|}{ With individual intercept \& trend } & \multicolumn{3}{c|}{ Without intercept \& trend } \\
\hline & $\begin{array}{c}\text { LLC } \\
\text { T-Stat }\end{array}$ & $\begin{array}{c}\text { Breitung } \\
\text { T-Stat }\end{array}$ & $\begin{array}{c}\text { IPS } \\
\text { W-Stat }\end{array}$ & $\begin{array}{c}\text { ADF Fisher } \\
\text { Chi-Square }\end{array}$ & $\begin{array}{c}\text { PP Fisher } \\
\text { Chi-Square }\end{array}$ & $\begin{array}{c}\text { LLC } \\
\text { T-Stat }\end{array}$ & $\begin{array}{c}\text { ADF Fisher } \\
\text { Chi-Square }\end{array}$ & $\begin{array}{c}\text { PP Fisher } \\
\text { Chi-Square }\end{array}$ \\
\hline $\operatorname{In}(\mathrm{Y} / \mathrm{L})$ & $-1.7865^{*}$ & 3.4452 & 0.8006 & 8.5842 & 4.3754 & 3.2327 & 1.6031 & 1.0831 \\
\hline $\ln (\mathrm{Kd})$ & -1.0599 & -0.3054 & 0.1258 & 11.500 & 9.1983 & 1.7113 & 1.3832 & 1.5116 \\
\hline $\operatorname{In}(\mathrm{K} / \mathrm{L})$ & $-2.1091^{*}$ & $-2.1752^{* *}$ & -1.1514 & 16.686 & 16.961 & 1.5612 & 2.3409 & 1.6685 \\
\hline $\operatorname{In}(\mathrm{M})$ & 2.0341 & $-1.7484^{*}$ & 0.5448 & 8.2904 & $21.006^{*}$ & 4.3603 & 0.7280 & 0.1001 \\
\hline $\ln (\mathrm{D})$ & 0.2528 & $-1.2968^{*}$ & -0.3779 & 14.743 & 9.5088 & -0.0732 & 8.6875 & 8.4266 \\
\hline $\ln (H)$ & -0.8593 & -0.4957 & -0.2634 & 16.500 & $20.327^{*}$ & 4.7635 & 0.5792 & 0.0055 \\
\hline
\end{tabular}

Note: The Breitung and IPS tests are not available for panel Unit Root tests without individual intercept and trend. ${ }^{*} p<0.1 ;{ }^{*} p<0.05 ;{ }^{*}{ }^{*} p<0.01$ 
Table 3: Panel Unit Root tests on series in first differences

\begin{tabular}{|c|c|c|c|c|c|c|c|c|}
\hline & \multicolumn{5}{|c|}{ With individual intercept $\&$ trend } & \multicolumn{3}{|c|}{ Without intercept \& trend } \\
\hline & $\begin{array}{l}\text { LLC } \\
\text { T-Stat }\end{array}$ & $\begin{array}{l}\text { Breitung } \\
\text { T-Stat }\end{array}$ & $\begin{array}{c}\text { IPS } \\
\text { W-Stat }\end{array}$ & $\begin{array}{l}\text { ADF Fisher } \\
\text { Chi-Square }\end{array}$ & $\begin{array}{c}\text { PP Fisher } \\
\text { Chi-Square }\end{array}$ & $\begin{array}{l}\text { LLC } \\
\text { T-Stat }\end{array}$ & $\begin{array}{l}\text { ADF Fisher } \\
\text { Chi-Square }\end{array}$ & $\begin{array}{l}\text { PP Fisher } \\
\text { Chi-Square }\end{array}$ \\
\hline $\ln (Y / L)$ & $-6.8196 * * *$ & $-4.5733 * * *$ & $-5.5717 * * *$ & $48.145^{* * *}$ & $39.343^{* * *}$ & $-4.1752 * * *$ & $42.815^{* * *}$ & $69.855^{* * *}$ \\
\hline $\ln (K d)$ & $-3.8918 * * *$ & $-2.1140 * *$ & $-4.4567^{* * *}$ & $40.963 * * *$ & $109.22 * * *$ & $-5.7291 * * *$ & $48.006^{* * *}$ & $83.591 * * *$ \\
\hline $\ln (K / L)$ & $-8.1244 * * *$ & $-6.3534 * * *$ & $-6.9608^{* * *}$ & $59.948 * * *$ & $82.913^{* * *}$ & $-9.0026^{* * *}$ & $78.077^{* * *}$ & $121.73^{* * *}$ \\
\hline $\ln (M)$ & $-4.4108 * * *$ & $-4.1984 * * *$ & $-6.3486 * * *$ & $56.764 * * *$ & $125.96 * * *$ & $-5.6521 * * *$ & $44.462 * * *$ & $60.469 * * *$ \\
\hline $\ln (D)$ & $-5.0606 * * *$ & $-6.9331 * * *$ & $-6.0387 * * *$ & $52.065^{* * *}$ & $58.569 * * *$ & $-7.9641 * * *$ & $67.819 * * *$ & $106.92 * * *$ \\
\hline $\ln (H)$ & $-5.9952 * * *$ & $-2.2540 * *$ & $-3.7778 * * *$ & $33.242 * * *$ & $59.876 * * *$ & $-2.6667 * * *$ & 17.058 & $44.858 * * *$ \\
\hline
\end{tabular}

Note: The Breitung and IPS tests are not available for panel Unit Root tests without individual intercept and trend. ${ }^{*} p<0.1 ;{ }^{* *} p<0.05 ; * * * p<0.01$

Once the preconditions of $I(1)$ and cointegration are fulfilled, equation [26] can be estimated using the Fully Modified Ordinary Least Squares (FMOLS) method. Originally designed by Phillips and Hansen (1990), this method modifies Ordinary Least Squares $(O L S)$ to provide optimal estimates of cointegrating regressions by accounting for serial correlation effects and for the endogeneity in the regressors that results from the existence of a cointegrating relationship (Phillips, 1993). The specific options of pooled method (allowing for heterogeneous first-stage long-run coefficients), constant trend specification, non-lag specification, and Bartlett Kernel and Newey-West Fixed bandwidth long-run covariance estimates are selected. In order to test the likelihood of the model, however, parallel estimations are made using different sets of independent variables, as grouped in Table 1 by theories. Moreover, an additional 'All Theories' estimation including all of the independent variables simultaneously is carried out. This enables us to check that the signs of the coefficients hold with different combinations of controls. Table 4 shows these results.

Table 4 shows that our capital distribution variable $(\ln (K d))$ is significant in all of the regressions except for the Sokoloff-Engerman estimation. However, most importantly, we can see that it always holds a negative sign, as expected, meaning that there exists a negative relationship between economic growth and capital income inequality. As for the other variables, we note that they all appear very significant in every estimation with the expected positive sign, except for the 'democracy' variable $(\ln (D))$, which always enters with a negative sign in the regressions, although it is never significant. Thus, the evidence does not reject and is consistent with the theory presented in this work, according to which there is a negative relation between productive capital inequality and economic growth.

In order to ascertain the direction of predictability of the above found relationship between $\ln (\mathrm{Y} / \mathrm{L})$ and $\ln (\mathrm{Kd})$, we also perform panel Granger Causality tests in Table 5. The test evaluates how much of the current value of one variable can be explained by its own past values, and how much can be explained by the lagged values of the other. However, since it is well known that the result is sensitive to the 
number of lags or years into the past chosen to evaluate this effect, the test is carried out for a considerable number of lags.

Table 4: Panel FMOLS Results

\begin{tabular}{|c|c|c|c|c|c|}
\hline & \multicolumn{5}{|c|}{ Theory } \\
\hline & $\begin{array}{c}\text { Growth \& } \\
\text { Distribution }\end{array}$ & Solow- Swan & Lewis & $\begin{array}{l}\text { Sokoloff- } \\
\text {-Engerman }\end{array}$ & All Theories \\
\hline \multirow[t]{2}{*}{$\ln (K d)$} & $-1.0846 * * *$ & $-0.5028 * * *$ & $-0.7281 * * *$ & -0.0516 & $-0.1043^{*}$ \\
\hline & $(0.0425)$ & $(0.0504)$ & (0.0483) & (0.0590) & $(0.0624)$ \\
\hline \multirow[t]{2}{*}{$\ln (K / L)$} & & $0.5106^{* * *}$ & & & $0.3797 * *$ \\
\hline & & $(0.0739)$ & & & $(0.0872)$ \\
\hline \multirow[t]{2}{*}{$\ln (M)$} & & & $1.9185^{* * *}$ & & $1.2309 * * *$ \\
\hline & & & $(0.0406)$ & & $(0.0587)$ \\
\hline \multirow[t]{2}{*}{$\ln (D)$} & & & & -0.0548 & -0.0079 \\
\hline & & & & $(0.0521)$ & $(0.0571)$ \\
\hline \multirow[t]{2}{*}{$\ln (H)$} & & & & $0.6892^{* * *}$ & $0.1974 * * *$ \\
\hline & & & & $(0.0170)$ & $(0.0230)$ \\
\hline$R 2$ & 0.9726 & 0.9792 & 0.9789 & 0.9828 & 0.9872 \\
\hline Adjusted R2 & 0.9712 & 0.9779 & 0.9776 & 0.9816 & 0.9860 \\
\hline S.E. of reg. & 0.1061 & 0.0928 & 0.0935 & 0.0847 & 0.0738 \\
\hline $\begin{array}{l}\text { Unbalanced } \\
\text { panel obs. }\end{array}$ & 125 & 120 & 125 & 125 & 120 \\
\hline
\end{tabular}

Note: ${ }^{*} p<0.1 ;{ }^{*} p<0.05 ;{ }^{*}{ }^{*} p<0.01$

Standard errors within ()

Table 5: Panel Granger Causality test results

\begin{tabular}{cccc}
\hline Lags & $\begin{array}{c}\mathrm{N} 0: \ln (\mathrm{Y} / \mathrm{L}) \text { does not granger-cause } \ln (\mathrm{Kd}) \\
\text { F-Statistic }\end{array}$ & $\begin{array}{c}\mathrm{N} 0: \ln (\mathrm{Kd}) \text { does not granger-cause } \ln (\mathrm{Y} / \mathrm{L}) \\
\text { F-Statistic }\end{array}$ & Obs. \\
\hline 1 & 0.0000 & 0.5806 & 120 \\
2 & 1.0891 & 1.2649 & 114 \\
3 & 1.5515 & $2.8263^{* *}$ & 108 \\
4 & 1.3132 & $2.2728^{*}$ & 96 \\
5 & 1.2203 & $4.1272^{* *}$ & 90 \\
6 & 0.7628 & $2.7634^{* *}$ & 90 \\
7 & 0.5162 & $2.2458^{* *}$ & 84 \\
9 & 0.6431 & $1.8075^{*}$ & 78 \\
\hline
\end{tabular}

${ }^{*} p<0.1 ;{ }^{*} p<0.05 ;{ }^{* *} p<0.01$

The results in Table 5 strongly support the hypothesis that $\ln (K d)$ does granger-cause $\ln (Y / L)$ in the full range of lags 3 to 8 . The order of causality seems to go from capital income distribution to growth, and not the other way around. This is consistent with our theory, where productive capital distribution directly affects growth 
and the level of output through the mechanism of the Law of Diminishing Returns to capital, which eventually enhances them at the point of equal distribution, $K_{A B}^{* *}$.

\section{CONCLUSIONS}

We build upon an already known but scarcely developed feature of growth theory: the importance of asset distribution in an aggregate production function, to develop a growth model of Ricardian inspiration. In our model, capital inequality and income growth are simultaneously (endogenously) determined. The model builds upon marginal diminishing returns and proves that a perfectly equal distribution of capital determines the maximum income per capita. We present first a two-agent model, and then extend it to the $n$-agents case.

In contrast with neoclassical models: a) we do not rely on representative agent or exogenous technical change, but in the distribution of capital between members of society; and b) in absence of external shocks, our model does not converge to a steady-state of zero growth, but to positive growth and perfect distribution. We show that this framework has already been implicitly used by many authors, who have transformed original Kuznetian models into current "asset inequality" models, with their corresponding empirical analyses and proofs.

We undertake a panel test of the theory, using six Latin American countries for the period 1990-2011. The regression strongly and significantly favours our theory of growth and distribution, in a context that includes variables that represent alternative growth theories (capital accumulation, industrialization institutions, and education). The results are robust to panel specification and cointegration tests, but we must be cautious about the results because of the small size of the sample. Empirical research using larger and more comprehensive datasets will be performed in the future, in order to continue building upon our theoretical framework.

\section{REFERENCES}

Aisen, A. \& F. Veiga (2013), How does political instability affect economic growth? European Journal of Political Economy 29, 151-167

Beladi, H., C. Chao, \& D. Hollas (2013), How growing asset inequality affects developing economies. Journal of Economics and Business 68, 43-51.

Birdsall, N. \& J. Londoño (1997), Asset inequality matters: an assessment of the World Bank's approach to poverty reduction. The American Economic Review 87(2), Papers and Proceedings of the Hundred and Fourth Annual Meeting, 32-37.

Caballero, E. (1970), Historia económica de Colombia. Bogotá: Banco de Bogotá.

Castelló, A. \& R. Doménech (2002), Human capital inequality and economic growth: some new evidence. The Economic Journal 112(478), C187-C200.

Chang, H. (2011), Institutions and economic development: theory, policy and history. Journal of Institutional Economics 7(4), 473-498.

Deininger, K. \& P. Olinto (2000), Asset distribution, inequality, and growth. World Bank - Policy Research Working Paper 2375.

Deininger, K. \& L. Squire (1996). A new data set measuring income inequality. World Bank Economic Review 10(3), 565-591.

Doucouliagos, H. \& M. Ulubaşoğlu (2008), Democracy and economic growth: a meta-analysis. American Journal of Political Science 52(1), 61-83. 
Engerman, S. \& K. Sokoloff (2012), Economic Development in the Americas since 1500: Endowments and Institutions. NBER - Cambridge University Press, Cambridge UK.

Fort, R. (2007), Land inequality and economic growth: a dynamic panel data approach. Agricultural Economics 37, 159-165.

Frankema, E. (2010), The colonial roots of land inequality: geography, factor endowments, or institutions? The Economic History Review 63(2), 418-451.

Garza, N. \& G. Pugliese (2009), Elección teórica en economía: el caso de Solow, Romer y Ramsey. Cuadernos de Economia 50, 38-62.

Glaeser, et al. (2004), Do institutions cause growth? Journal of Economic Growth 9(3), 271-303.

Gollin, D.; R. Jedwab \& D. Vollrath (2016), Urbanization with and without industrialization. Journal of Economic Growth 21, 35-70.

Grinberg, N. (2015), On the Brazilian ground-rent appropriated by landowners. Brazilian Journal of Political Economy 35(4), 799-824.

Harris, J. \& M. Todaro (1970). Migration, unemployment and development: A two-sector analysis. American Economic Review 60(1), 126-142.

Hobbes, T. (2010), Leviatán: o la Materia, Forma y Poder de una República Eclesiástica y Civil. México: Fondo de Cultura Económica.

Hugo, V. (1887), Les Misérables. New York: Thomas Y. Crowell \& Co. Retrieved from: http://www.gutenberg.org/files/135/135-h/135-h.htm

Irmen, A. \& R. Klump (2009), Factor substitution, income distribution and growth in a generalized neoclassical model. German Economic Review 10(4), 464-479.

Kaldor, N. (1955), Alternative theories of distribution. The Review of Economic Studies 23(2) 83-100.

Kuznets, S. (1955), Economic growth and income inequality. The American Economic Review 45(1), 1-28.

Lewis, W. (1954), Economic development with unlimited supplies of labour. The Manchester School 22(2), 139-191.

Mo, P. (2003), Land distribution inequality and economic growth: transmission channels and effects. Pacific Economic Review 8(2), 171-181.

Pasinetti, L. (1962), Rate of profit and income distribution in relation to the rate of economic growth. The Review of Economic Studies 29(4), 267-279.

Phillips, P. (1993). Fully Modified Least Squares and Vector Autoregression. Cowles Foundation - discussion paper 1047.

Phillips, P. \& B. Hansen (1990), Statistical inference in instrumental variables regressions with I(1) processes. Review of economic studies 57, 99-125.

Pikkety, T. \& G. Zucman (2014), Capital is Back: Wealth-Income Ratios in Rich Countries, 1700-2010. Quarterly Journal of Economics 129(3), 1255-1310.

Ricardo, D. (1985). Principios de Economía Política. Madrid: Sarpe.

Ros, J. (2013), Rethinking Economic Development, Growth, and Institutions. Oxford University Press, UK.

Rosenstein-Rodan, P. (1943), Problems of industrialization of Eastern and Southern-Eastern Europe. Economic Journal 53, 202-211.

Saez, E. \& G. Zucman (2016), Wealth inequality in the United States since1913: evidence from capitalized income tax data. The Quarterly Journal of Economics 131(2), 519-578.

Sen, A. (1997), From income inequality to economic inequality. Southern Economic Journal 64(2), 383401.

Solow, R. (1956), A contribution to the theory of economic growth. Quarterly Journal of Economics 70(1), $65-94$.

Stiglitz, J. (1969), Distribution of income and wealth among individuals. Econometrica 37(3), 382-397.

United Nations Conference on Trade and Development (1998), Income distribution, capital accumulation, and growth. Challenge 41(2), 61-80.

Williams, C \& S. Nadine (2012), Tackling the hidden enterprise culture: Government policies to support the formalization of informal entrepreneurship. Entrepreneurship \& Regional Development 24(9), 895-915. 